\title{
COVID-19 presenting with diarrhoea and hyponatraemia
}

\author{
Fateen Ata ำ , Hussam Almasri ำ , Jamal Sajid, Zohaib Yousaf
}

Internal Medicine, Hamad Medical Corporation Department of Medical Education, Doha, Qatar

\section{Correspondence to Dr Zohaib Yousaf; zohaib.yousaf@gmail.com}

Accepted 27 May 2020
Check for updates

(C) BMJ Publishing Group Limited 2020. No commercial re-use. See rights and permissions. Published by BMJ.

To cite: Ata $\mathrm{F}$, Almasri $\mathrm{H}$, Sajid J, et al. BMJ Case

Rep 2020;13:e235456.

doi:10.1136/bcr-2020-

235456

\section{SUMMARY}

COVID-19 is a viral disease with a high infectivity rate. The full spectrum of the disease is not yet understood. This understanding may help in limiting potential exposure. We present a young man with diarrhoea, abdominal pain and hyponatraemia who turned out to be positive for COVID-19.

\section{BACKGROUND}

COVID-19 is caused by the novel severe acute respiratory syndrome coronavirus 2 (SARS-CoV-2). Fever is a common presenting symptom, along with cough, dyspnoea, myalgia and fatigue. Severe cases may lead to organ dysfunction and death. ${ }^{1}$

As with any infectious disease, one of the challenges with COVID-19 is to understand both the typical and atypical disease presentations. Atypical presentations carry the risk of going undetected for a longer duration, and in turn may lead to the spillover of the disease in a healthcare setting as well as the community.

\section{CASE PRESENTATION}

A 27-year-old Indian man, with known type 2 diabetes, presented with a 5-day history of gradually progressive, moderate severity, generalised abdominal pain. The pain was accompanied by watery diarrhoea five to six times per day. He did not have any fever, sore throat, myalgias, influenzalike symptoms or shortness of breath. A review of systems was remarkable for dry cough of similar duration.

There was no recent history of travel and no sick contacts or animal exposure.

On initial presentation, he was not febrile, tachypnoeic, tachycardiac or hypotensive. Physical examination revealed a patient in distress due to abdominal pain. There was mild generalised abdominal tenderness, but no guarding, rigidity or rebound. The chest examination showed coarse bibasal crackles. The rest of the physical examination was unremarkable.

Initial work-up revealed normocytic anaemia, thrombocytopaenia and non-elevated inflammatory markers. Two repeated samples confirmed asymptomatic hyponatraemia. Liver enzymes, renal function and the endocrine panel were unremarkable. Syndrome of inappropriate antidiuretic hormone secretion (SIADH) was the probable cause of hyponatraemia (table 1 ).
On the first day of admission, the patient developed high-grade fever. He was placed under isolation and screened for viral respiratory infections. The patient turned out to be positive for COVID-19.

\section{DIFFERENTIAL DIAGNOSIS}

Given the patient's chief complaint of abdominal pain with diarrhoea, gastroenteritis was the initial working diagnosis. There was no food intake from outside and no sick contacts. Stool analysis for ova and parasites was negative. Also, ELISA immunoassay for Clostridium difficile toxin came out negative. Stool culture was unrevealing. Stool PCR for SARS-CoV-2 was unavailable in the local hospital lab.

Pancreatitis was another differential, but lipase was negative. Atypical pneumonia was another possibility considering the minimal respiratory symptoms and bilateral chest X-ray findings (figure 1). The patient did not produce any sputum for culture, and two sets of blood cultures were negative. Due to hyponatraemia, Legionella pneumonia was considered; however, the urinary antigen was negative.

Viral pneumonia was another diagnostic possibility for which a viral panel was sent, which included SARS-CoV-2 PCR, which eventually came back positive and hence confirmed the diagnosis of the novel coronavirus pneumonia (table 2).

\section{TREATMENT}

The patient was initially started on ceftriaxone, azithromycin and oseltamivir as empirical therapy for community-acquired pneumonia. After the tests for COVID-19 PCR from nasal swab came positive, the patient received chloroquine phosphate $250 \mathrm{mg}$ two times per day, darunavir/cobicistat $950 \mathrm{mg}$ daily and ribavirin $1200 \mathrm{mg}$ two times per day for 14 days, based on local guidelines. Ribavirin $1200 \mathrm{mg}$ two times per day was added to his antiviral regimen. The patient remained clinically stable throughout the hospital course until discharge.

\section{OUTCOME AND FOLLOW-UP}

The patient's abdominal pain and diarrhoea resolved without any specific management. He did not require any ventilatory support during his stay. His SARS-CoV-2 PCR turned negative on repeat testing after 2 weeks and he was discharged home. 


\begin{tabular}{ll}
\hline Table 1 & Laboratory work-up on admission \\
\hline White cell count & $4.6 \times 10^{9} / \mathrm{L}$ \\
\hline Red blood cells & $4 \times 10^{12} / \mathrm{L}$ \\
\hline Haemoglobin & $110 / \mathrm{L}$ \\
\hline Mean cell volume & $85.6 \mathrm{fL}$ \\
\hline Mean cell haemoglobin & $27.8 \mathrm{pg}$ \\
\hline Platelets & $110 \times 10^{3} / \mathrm{LL}$ \\
\hline Glucose & $14.4 \mathrm{mmol} / \mathrm{L}$ \\
\hline Sodium corrected for glucose & $120 \mathrm{mmol} / \mathrm{L}$ \\
\hline Osmolality, serum & $298 \mathrm{mmol} / \mathrm{kg}$ \\
\hline Osmolality, urine & $789 \mathrm{mmol} / / \mathrm{K}$ \\
\hline Sodium, urine & $73 \mathrm{mmol} / \mathrm{L}$ \\
\hline Procalcitonin & $0.5 \mu \mathrm{g} / \mathrm{L}$ \\
\hline C reactive protein & $118 \mathrm{mg} / \mathrm{L}$ \\
\hline
\end{tabular}

\section{DISCUSSION}

The novel coronavirus belongs to a group of severe acute respiratory syndrome-related coronaviruses. ${ }^{2}$ It originated in Wuhan, Hubei Province, China, in December 2019 and was declared a pandemic by WHO on 11 March $2020 .^{3}$

The most common clinical features are fever, dry cough, myalgia, anorexia and dyspnoea. ${ }^{4}$ Gastrointestinal symptoms such as diarrhoea, abdominal pain and vomiting have been previously seen with acute viral respiratory infections and reported recently as rare manifestations of COVID-19. ${ }^{4-6}$ The confirmation of a suspected case relies on SARS-CoV-2 RNA detection via PCR.

Watery diarrhoea is present in SARS-CoV-1 infection secondary to virus replication within the intestinal cells. ${ }^{7}$

The presence of gastrointestinal symptoms in coronavirus infection (SARS-CoV-1 and SARS-CoV-2) can be linked to the distribution of ACE2 receptor, which is present in lung alveolar type 2 cells, as well as in enterocytes. ${ }^{8}$

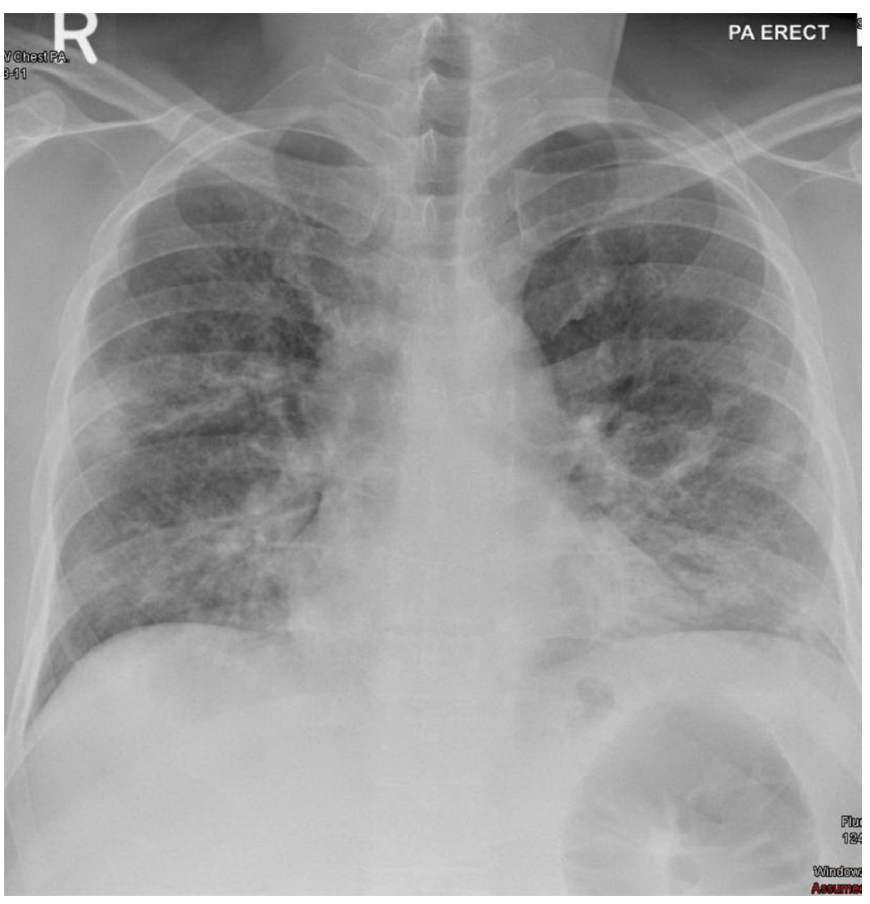

Figure 1 Chest X-ray showing bilateral infiltrates, more on the bases. $\mathrm{PA}$, posteroanterior.

\begin{tabular}{ll}
\hline Table 2 & Work-up for infective aetiology \\
\hline Blood cultures (2 sets) & Negative \\
\hline Stool culture & Negative \\
\hline Stool for ova/parasite & Negative \\
Stool for Clostridium difficile (ELISA Ab) & Negative \\
Respiratory syncytial virus & Negative \\
Parainfluenza & Negative \\
Influenza virus A PCR & Negative \\
Influenza virus B PCR & Negative \\
\hline Rhinovirus PCR & Negative \\
COVID-19 PCR & Positive \\
Legionella Ag & Negative \\
\hline
\end{tabular}

$A b$, antibody; Ag, antigen.

Acute hyponatraemia is present in atypical pneumonia, especially Legionella. ${ }^{9}$ The underlying mechanism is the syndrome of inappropriate antidiuretic hormone $(\mathrm{ADH})$ secretion. $^{10}$

There is a rapidly accumulating body of knowledge regarding the epidemiology, pathophysiology, clinical manifestations, infection control and management of COVID-19. Like any other RNA virus, SARS-CoV-2 attacks the host cell, and penetrates and enters the nucleus for replication. The virus has an affinity to ACE2 as binding receptors. ${ }^{11}$ This affinity is the probable reason that the lungs are the most commonly affected organs.

The response of the host organ can be from minimal symptoms to organ failure. $\mathrm{T}$ cell immune response to the coronaviruses has been studied in the past. ${ }^{12}$ Another common disease phenomenon observed and reported is a hypercoagulable state, which can be explained by the expression of ACE2 enzymes by the endothelium. ${ }^{13}$ Similarly, the gastrointestinal tract also expresses ACE2, leading to a viral attack of the system. ${ }^{14}$

There is ongoing research to understand the pathophysiology of COVID-19 infection.

An important aspect is to understand the atypical presentation of the disease. Timely detection of suspected cases with prompt isolation and screening is one of the factors that may help curb the spread in the community. ${ }^{15}$ Our patient had acute hyponatraemia, abdominal pain and diarrhoea with minimal

\section{Patient's perspective}

I am having a difficult time because of this pain in my stomach. Nothing has changed in my diet, and I have been following my same daily routine, but I do not understand why I have this pain and diarrhea. I hope it is some kind of a minor infection and goes as speedily as it came. (The perspective is from the initial encounter.)

\section{Learning points}

- Knowing the atypical presentation of the disease is as important as knowing a typical presentation.

- Anyone with gastrointestinal symptoms with no alternative explanation should be isolated and screened for COVID-19.

- Early screening may impact the spread of the disease.

- We recommend studies to evaluate the effectiveness of stool PCR for severe acute respiratory syndrome coronavirus 2 if initial nasopharyngeal PCR is negative and suspicion remains high. 
respiratory symptoms, which he did not self-report. The cough history was elicited during a thorough review of the system. This atypical presentation led to inadvertent exposure to healthcare personnel. Therefore, during the pandemic, a similar presentation should be considered for COVID-19.

Twitter Zohaib Yousaf @zohaibyousaf17

Acknowledgements The authors would like to acknowledge Miss Jyotei Lakshmi for helping expedite the research committee's approval for this case report.

Contributors FA was involved with case identification, informed consent and manuscript write-up. HA was involved in patient follow-up and literature review. IS diagnosed the case and treated the patient as an attending. ZY performed a literature review, and was involved in the initial manuscript write-up and in the final manuscript review as the senior author.

Funding The authors have not declared a specific grant for this research from any funding agency in the public, commercial or not-for-profit sectors.

Competing interests None declared.

Patient consent for publication Obtained.

Provenance and peer review Not commissioned; externally peer reviewed.

This article is made freely available for use in accordance with BMJ's website terms and conditions for the duration of the covid-19 pandemic or until otherwise determined by BMJ. You may use, download and print the article for any lawful, non-commercial purpose (including text and data mining) provided that all copyright notices and trade marks are retained.

\section{ORCID iDs}

Fateen Ata http://orcid.org/0000-0001-7121-8574

Hussam Almasri http://orcid.org/0000-0002-9549-8352

Zohaib Yousaf http://orcid.org/0000-0002-4631-9899

\section{REFERENCES}

1 Zhou F, Yu T, Du R, et al. Clinical course and risk factors for mortality of adult inpatients with COVID-19 in Wuhan, China: a retrospective cohort study. Lancet 2020;395:1054-62.

2 Gorbalenya A, Baker S, Barik R, et al. The species severe acute respiratory syndromerelated coronavirus: classifying 2019-nCoV and naming it SARS-CoV-2. Nat Microbiol 2020;5:536-44.

3 Who.int. WHO Director-General's opening remarks at the media briefing on COVID-19 - 11 March 2020 [Internet], 2020. Available: https://www.who.int/dg/speeches/detail/ who-director-general-s-opening-remarks-at-the-media-briefing-on-covid-19-11march-2020 [Accessed 19 Mar 2020].

4 Wang D, Hu B, Hu C, et al. Clinical characteristics of 138 hospitalized patients with 2019 novel coronavirus-infected pneumonia in Wuhan, China. JAMA 2020;323:1061.

5 Minodier L, Masse S, Capai L, et al. Clinical and virological factors associated with gastrointestinal symptoms in patients with acute respiratory infection: a two-year prospective study in general practice medicine. BMC Infect Dis 2017;17:729.

6 Huang C, Wang Y, Li X, et al. Clinical features of patients infected with 2019 novel coronavirus in Wuhan, China. The Lancet 2020;395:497-506.

7 Ksiazek TG, Erdman D, Goldsmith CS, et al. A novel coronavirus associated with severe acute respiratory syndrome. N Eng/ J Med 2003;348:1953-66.

8 Gu J, Han B, Wang J. COVID-19: gastrointestinal manifestations and potential fecaloral transmission. Gastroenterology 2020;158:1518-9.

9 Fraser DW, Tsai TR, Orenstein W, et al. Legionnaires' disease. New England Journal of Medicine 1977;297:1189-97.

10 Dhawan A, Narang A, Singhi S. Hyponatraemia and the inappropriate ADH syndrome in pneumonia. Ann Trop Paediatr 1992;12:455-62.

11 Yuki K, Fujiogi M, Koutsogiannaki S. COVID-19 pathophysiology: a review. Clin Immunol 2020;108427.

12 Channappanavar R, Zhao J, Perlman S. T cell-mediated immune response to respiratory coronaviruses. Immunol Res 2014;59:118-28.

13 Lovren F, Pan Y, Quan A, et al. Angiotensin converting enzyme-2 confers endothelial protection and attenuates atherosclerosis. Am J Physiol Heart Circ Physiol 2008;295:H1377-84

14 Zhang H, Kang ZJ, Gong HY, et al. The digestive system is a potential route of 2019nCov infection: a bioinformatics analysis based on single-cell transcriptomes. Preprint. posted online January 30, 2020. bioRxiv 2020;927806.

15 Jamison DTG. Disease control priorities. 3rd ed. Washington, DC: The International Bank for Reconstruction and Development / The World Bank, 2017.

Copyright 2020 BMJ Publishing Group. All rights reserved. For permission to reuse any of this content visit

https://www.bmj.com/company/products-services/rights-and-licensing/permissions/

BMJ Case Report Fellows may re-use this article for personal use and teaching without any further permission.

Become a Fellow of BMJ Case Reports today and you can:

- Submit as many cases as you like

Enjoy fast sympathetic peer review and rapid publication of accepted articles

- Access all the published articles

Re-use any of the published material for personal use and teaching without further permission

Customer Service

If you have any further queries about your subscription, please contact our customer services team on +44 (0) 2071111105 or via email at support@bmj.com.

Visit casereports.bmj.com for more articles like this and to become a Fellow 